\title{
EHMTI-0264. Differences of some cytochemical parameters in persons with and without migraine
}

\author{
A Plinta ${ }^{1 *}$, I Logina ${ }^{2}$, P Tretjakovs ${ }^{3}$, R Erts $^{4}$, G Bahs ${ }^{5}$ \\ From 4th European Headache and Migraine Trust International Congress: EHMTIC 2014 \\ Copenhagen, Denmark. 18-21 September 2014
}

\section{Background}

Diagnosis of migraine currently based only on clinical symptoms and exclusion of secondary headache. Useful screening method of migraine is still unmet medical need.

\section{Aim}

Comparison of some cytochemical parameters in persons, suffering from migraine and healthy volunteers, and evaluate sensitivity of each parameter in case of significant difference between both groups.

\section{Materials and methods}

49 persons suffering from migraine, only women $(42,1 \pm$ 9,3 y.o.) and 30 gender, age and body mass index matched healthy volunteers $(38,2 \pm 5,5$ y.o. $)$ were included in trial. Cytochemical parameters were evaluated: interferon gamma (IFN-g), interleukin-10 (IL-10), interleukin-8 (IL-8), interleukin-17 (IL-17), plasminogen activator inhibitor type 1 (TPAI-1), matrix metallopeptidase-9 (MMP-9), soluble cell adhesion molecules (SVCAM-1, SICAM-1), transforming growth factor alpha (TGF-alpha), monocyte chemotactic protein-1 (MCP-1), interleukin-1alpha (IL-1alpha), interleukin1beta (IL-1beta), interleukin-9 (IL-9). Levels of every parameter compared between groups. Statistic method of Mann-Whitney test used.

\section{Results}

It was revealed statistically significantly lower level of IFN-g ( $\mathrm{z}=2,60 ; \mathrm{p}, 0,001)$, IL-17 ( $\mathrm{z}=2,78 ; \mathrm{p}<0,001)$, TPAI-1 $(\mathrm{z}=2,19 ; \mathrm{p}<0,01)$, MMP-9 $(\mathrm{z}=2,60 ; \mathrm{p}<$ $0,02)$, SICAM-1 $(\mathrm{z}=2,76 ; \mathrm{p}<0,001)$ and TGF-alpha ( $\mathrm{z}$ $=2,52 ; \mathrm{p}<0,001)$ in migraine group. Evaluation of Area Under Curve (AUC) using Receiver Operating

${ }^{1}$ Doctoral studies Dept., RSU, Riga, Latvia

Full list of author information is available at the end of the article
Characteristic (ROC) method showed no significant difference in migraine and control groups $(\mathrm{AUC}=0,63-$ 0,68 in mentioned above parameters) .

\section{Conclusion}

It was statistically significant difference of cytokine levels in migraine patients and control group. However, it does not allow interpreting findings in terms of clinical screening

No conflict of interest.

\section{Authors' details}

'Doctoral studies Dept., RSU, Riga, Latvia. ${ }^{2}$ Riga Stradins University

Department of Neurology and Neurosurgery, RSU, Riga, Latvia. ${ }^{3}$ Riga Stradins University Department of Human Physiology and Biochemistry, RSU, Riga, Latvia. ${ }^{4}$ Riga Stradins University Department of Physics, RSU, Riga, Latvia.

${ }^{5}$ Riga Stradins University Department of Family Medicine, RSU, Riga, Latvia.

Published: 18 September 2014

doi:10.1186/1129-2377-15-S1-E26

Cite this article as: Plinta et al: EHMTI-0264. Differences of some

cytochemical parameters in persons with and without migraine.

The Journal of Headache and Pain 2014 15(Suppl 1):E26.

Submit your manuscript to a SpringerOpen ${ }^{\odot}$ journal and benefit from:

- Convenient online submission

- Rigorous peer review

- Immediate publication on acceptance

- Open access: articles freely available online

- High visibility within the field

- Retaining the copyright to your article

Submit your next manuscript at $\boldsymbol{~ s p r i n g e r o p e n . c o m ~}$ (c) 2014 Plinta et al; licensee Springer. This is an Open Access article distributed under the terms of the Creative Commons Attribution License (http://creativecommons.org/licenses/by/2.0), which permits unrestricted use, distribution, and reproduction in any medium, provided the original work is properly cited. 